Бочко О. Ю., д.е.н., проф., (Національний університет «Львівська політехніка», М. Львів), Малецька О. І., к.е.н, доц., (Львівський національний аграрний університет, м. Львів), Савіна Н. Б., д.е.н., професор (Національний університет водного господарства та природокористування, м. Рівне)

\title{
АНАЛІЗ ЕКСПОРТУ МОЛОЧНОЇ ПРОДУКЦІЇ В КОНТЕКСТІ РОЗШИРЕННЯ УМОВ ЕВРОІНТЕГРАЦІЇ
}

Стаття розкриває результати аналізу експорту молочної продукції в контексті розширення умов евроінтеграції. Встановлено, що серед молокопродуктів найбільше експортували масло вершкове, сири, а також молоко згущене. Подано динаміку експорту молочних продуктів та країн експортерів у 2017-2018 рр. Узагальнено та встановлено основні країни-експортери молочної продукції, серед яких Казакстан, Молдова, Марокко, Грузія, Китай, Вірменія. Виявлено причини динаміки зміни експорту молочної продукції. Внесено пропозиції для збільшення обсягів експорту молочної продукції. Ключові слова: експорт, молочна продукція, молоко, сировина, виробництво молока, країни-експортери.

ВСТУП. Молоко $є$ неохідною складовою раціону харчування кожної людини. Корисні властивості молока та молочних продуктів не можна переоцінити, оскільки саме в цьому продукті знаходиться необхідна кількість хімічних і біохімічних речовин. Доведено, що в цьому продукті міститься більше ста різних найцінніших для організму людини компонентів.

Аналіз останніх досліджень і публікацій. Виробництво молока і молокопродуктів в Україні $є$ одним із найбільш перспективних напрямів розвитку аграрного сектору економіки та основним джерелом зайнятості мешканців сільської місцевості. Дослідженням даної проблеми займались багато вчених, зокрема Т.В. Божидарнік обгрунтовувала зарубіжний досвід регулювання ринку молока, запропонувала окремі елементи імплементувати у вітчизняну практику; В. І. Бойко, Н. С. Белінська, П. С. Березівський, С. В. Васильчак, П. І. Гайдуцький, Т. Г. Дудар, П. Т. Саблук, здійснювали аналізування та прогнозування обсягів виробництва, реалізації та цінової політики молочної продукції; Л. А. Євчук, О. В. Мороз, Н. П. Карачина, Л. М. Несен, Л.С. Філатова обгрунтовували функціональності ринку молочної 
продукції в Україні; В.А. Лапідус, М.М. Ільчук, І.С. Полікарпов, І.В. Полуда, Е. Демінг, В.Ю. Огвоздін значний вклад зробили у розробку економічного аспекту розвитку молочної галузі. Проте на даний час досить мало праць розкривають проблеми експорту молочної продукції, її відповідність вимогам ЄС. Хоча за останні роки можна спостерігати покращення якості молочної продукції, зокрема зросла кількість молока екстра гатунку.

По при велику кількість наукових праць в досліджуваній сфері, не здійснено ґрунтовного дослідження щодо рівня обсягів експорту продукції через зміну підходів та умов до молочної продукції, яка експортується.

Метою даної статті $€$ висвітлення наукових підходів щодо аналізу та перспектив розвитку експорту молочної продукції в контексті розширення умов евроінтеграції.

Результати дослідження. Починаючи з 2018 року молочний сектор демонструє позитивні результати, покращилась якість сировини, вперше за останні роки Україна увійшла в 10-ку світових лідерів з експорту молочної продукції [10]. Зокрема за даними Державної митної служби України у 2018 році Україною імпортовано молокопродукції на суму 20,9 млн дол. США, що на 8,7 млн дол. (71,3\%) більше ніж у 2017 року (12,2 млн дол. США); експортовано молока та молокопродуктів на суму 68,5 млн дол. США. Порівняно з 2017 роком (45,4 млн дол. США) цей показник збільшився на 23,1 млн дол. США (на 50,9\%). Торговельне сальдо по даній товарній групі $€$ позитивним і становить 47,6 млн дол. США. Проти показника минулого року (33,2 млн дол. США) воно збільшилось на 14,4 млн дол. США [4].

В структурі експорту молочних продуктів у 2018 році найбільшу питому становило масло вершкове 181,4 тис. т (82,5\% від загального експорту молокопродуктів у перерахунку на молоко), сири 20,1 тис. т $(9,2 \%)$, молоко згущене 10,8 тис. т (4,9\%), молоко і вершки незгущені 2,9 тис. т (1,3\%), морозиво 2,6 тис. т (1,2\%), кисломолочна продукція 1,5 тис. т (0,7\%) та молочна сироватка - 0,6 тис. т (0,3\%) [6] (рис. 1).

Отже, за результатами рис. 1 серед молокопродуктів найбільше експортували масло вершкове та сири. Зокрема відмітимо, що дана продукція досить швидкими темпами експортувалася як в 2017 році так і в 2018 році.

Основними країнами - експортерами молочної продукції в 2017 році були Казахстан (реалізація продукції становила 15,4\%), Молдова (13,2\%), Китай (6,4\%) та Марокко (6,4\%) [6] (рис. 2). 

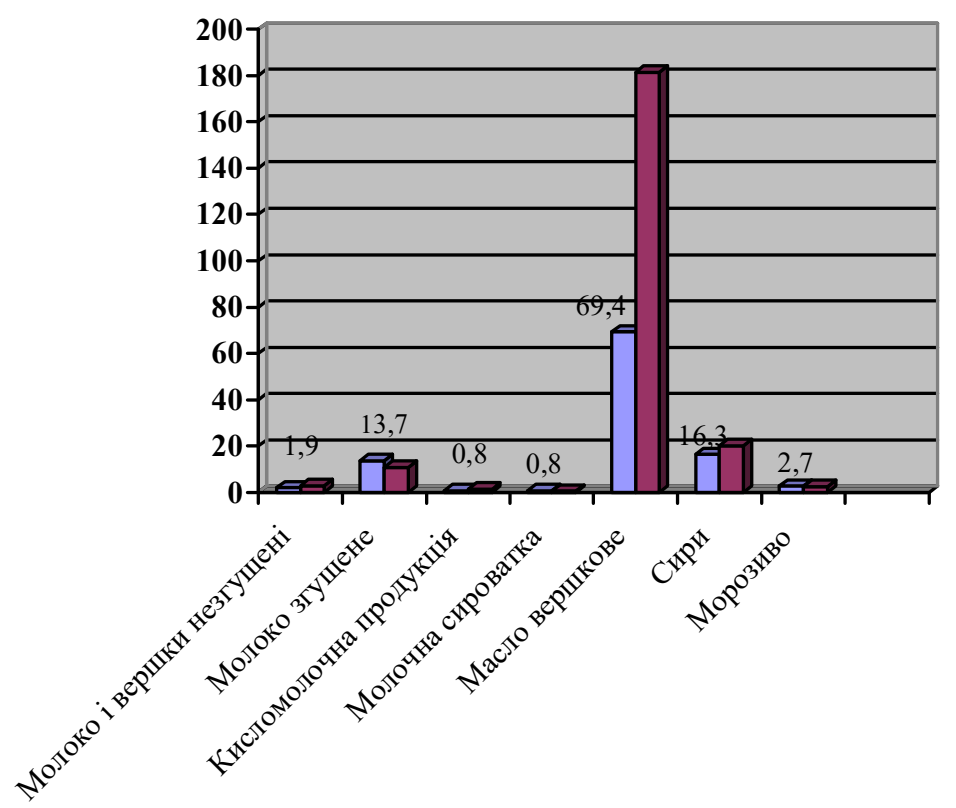

$$
\square 2017 \text { p. } \square 2018 \text { p. }
$$

Рис. 1. Динаміка експорту молочних продуктів у 2017-2018 рр., тис. т Джерело: $[4 ; 6]$

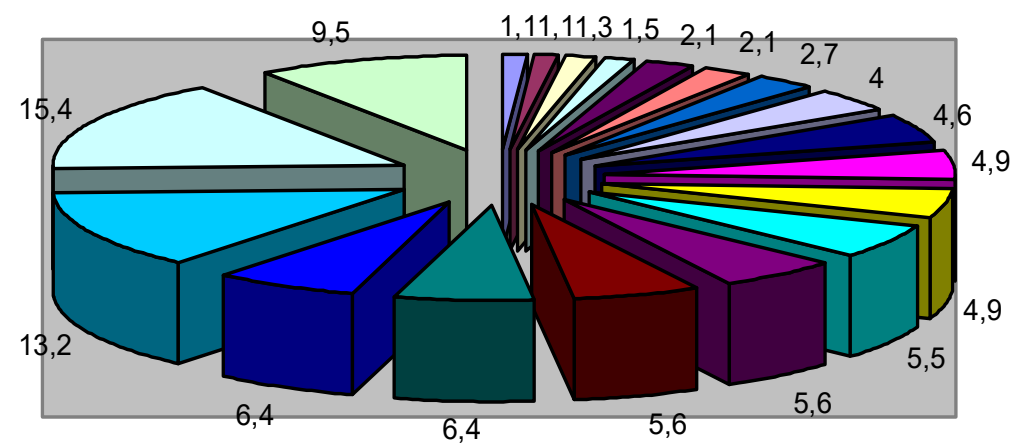

\begin{tabular}{|lllll|}
\hline$\square$ Йорданія & $\square$ Пакистан & $\square$ Філіпіни & $\square$ індія & $\square$ Росія \\
$\square$ Алжир & $\square$ Малайзія & $\square$ Ізраїль & $\square$ Бангладеш & $\square$ Сгипет \\
$\square$ Грузія & $\square$ Вірменія & $\square$ Азербайджан & $\square$ Туркменістан \\
$\square$ Марокко \\
$\square$ Китай & $\square$ Молдова & $\square$ Казахстан & $\square$ Інші & \\
\hline
\end{tabular}

Рис. 2. Основні країни експортери, 2017p.*

Джерело: [3; 4] 
Експорт молока та молокопродуктів у перерахунку на молоко у 2018 році становив 220 тис. т, що на 114,4 тис. т більше ніж у 2017 році, у якому даний показник становив (105,6 тис. т.)

У 2018 році Україна експортувала молокояної продукції на суму 68,5 млн дол. США в 74 країни. У 2017 році - 45,4 млн дол. в 58 країни. Загалом спостерігається зростання обсягів експорту молочної продукції на 23,1 млн дол. США (50,9\%).

У 2018 році молокопродукція переважно поставлялася до Туреччини, Марокко, Молдови, Казахстану, Грузії, Південної Африки, Саудівської Аравії, Азербайджану, Вірменії та Китаю, які займають від загальної суми (68,5 млн дол. США) експортованої молокопродукції відповідно: 14,5\% (9,9 млн дол. США), 13,1\% (9 млн), 10,3\% (7 млн), 8,4\% (5,7 млн), 7,2\% (4,9 млн), 4,8\% (3,3 млн), 4,3\% (3 млн), 4,2\% (2,9 млн) 4\% (2,7 млн) та 3,5\% (2,4 млн дол. США) [6] (рис. 3).

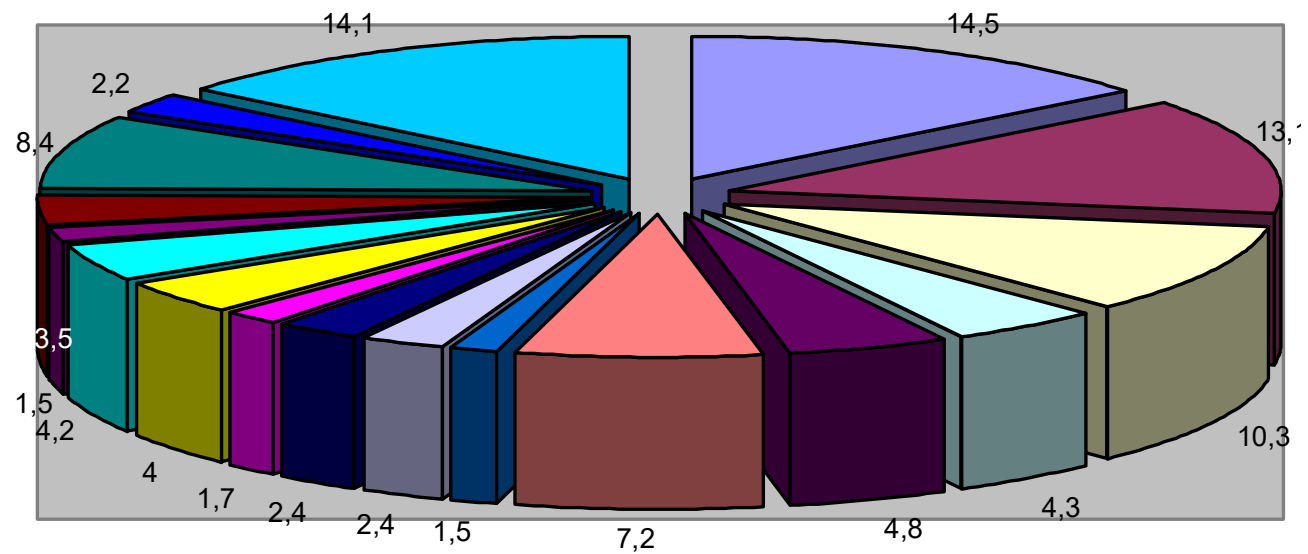

\begin{tabular}{|llll|}
\hline$\square$ Туреччина & $\square$ Марокко & $\square$ Молдова & $\square$ Саудівська Аравія \\
$\square$ Південна Африка & $\square$ Грузія & $\square$ Бангладеш & $\square$ Ізраїль \\
$\square$ Сгипет & $\square$ ОАЕ & $\square$ Вірменія & $\square$ Азербайджан \\
$\square$ Туркменістан & $\square$ Китай & $\square$ Казахстан & $\square$ Данія \\
$\square$ Інші & & & \\
\hline
\end{tabular}

Рис. 3. Основні країни експортери, 2018p.* Джерело: [3; 4]

У 2018 році зменшився експорт молокопродукції переважно до Казахстану на 7\%, Туркменістану - на 4,1\%, Бангладеш - на 3,1\%, Молдови - на 2,9\%, Китаю - на 2,9\%. Водночас збільшили за цей період присутність своєї молокопродукції на ринку України Туреччина на 14,5\%, Марокко - на 6,7\%, Південна Африка - на 4,5\%, Саудівська Аравія - на 3,7\%, Грузія - на 2,3\% [6]. 
«Державна фіскальна служба вже підбила підсумки зовнішньої торгівлі молочними продуктами в першому кварталі 2019 року. За звітними даними, Україна отримала від торгових операцій з молочними продуктами на 19\% менше, ніж за аналогічний період минулого року, - 53,9 млн дол. Це пояснюється просіданням торгівлі по всіх основних торгових групах: масло, сухе молоко, сир та сирний продукт» стверджує Музиченко Я. [9].

Загалом, динаміка зміни експорту молочної продукції повязана із різними причинами:

1) кожна країна має свої вподобання стосовно молочних продуктів виходячи з традицій або сучасної моди. Деякі звичні для українського ринку продукти можуть бути маловідомими або взагалі невідомими для споживачів інших країн і, відповідно, не мати перспектив масового збуту;

2) перед вибором напрямку експорту необхідно вивчити торгівельні режими. Деякі країни обмежують імпорт певної продукції для захисту внутрішніх виробників, обкладаючи його митом, та/або застосовуючи квоти на обсяги імпорту [0];

3) обов'язкова наявність в українських експортерів сертифікату EUR1. Він підтверджує походження партії товару з території України та, відповідно до Угоди про Асоціацію між Україною та ЄС, дає право на її преференційний (безмитний) імпорт до країн ЄС;

4) упаковка та етикетка повинна відповідати європейським стандартам, товар повинен бути високої якості та проходить суворий контроль безпеки;

5) ассортиментом, який повинен бути відкоригований відносно до вподобань європейського споживача.

\section{ВИСНОВКИ}

Для збільшення обсягів експорту продукції пропонуємо:

1. Створити інформаційну платформу, в межах якої потрібно надавати повний спектр послуг з підтримки зовнішньої торгівлі України. Основна мета побудова такої платформи: надання інформації про наявність ринків тта цінову політику на них, моніторинг законодавчого та інформаційного полів, надання повноцінної інформаційної підтримки експортноорієнтованим закордонним компаніям. Така платформа повинна також займатися електронною комерцією, активно взаємодіяти з традиційними формами гуртової та роздрібної торгівлі в автономному режимі.

2. В межах країни експортера знайти дистриб'ютора, що має важливе значення для успіху реалізації товару.

3. Збільшити рівень інвестицій у просування товару на міжна- 
родні ринки.

4. Максимізувати зусилля для пошуку власної ніші на ринку та зосередити увагу на ній.

5. Розробити механізм державного регулювання, який повинен враховувати економічні та правові функції та здійснювати комплекс засобів, важелів, методів та інструментів, у результаті чого забезпечується реалізація поставлених органами державної влади цілей.

6. Сформувати належну нормативно-законодавчу базу, що дало б змогу розвиватись вітчизняним підприємствам молочної промисловості та сприяло б їх виходу на міжнародні ринки.

Перспективним напрямком подальших досліджень $\epsilon$ обґрунтування методології дослідження та вчасне виявлення зовнішніх та внутрішніх чинників, що впливають на процес експортування молочної продукції.

1. Божидарнік Т. В. Теоретико-методологічні засади імплементації зарубіжного досвіду регулювання ринку молока у вітчизняну практику. Економічні науки. Сер. Економічна теорія та економічна історія. 2013. Вип. 10. С. 17-28. 2. Бурка А., Гонтар В., Кищук О., Костомаха В., Панкратов А., Поліщук Р., Шапоавал Б., Ярмак А. Практичний довідник експортера молочної продукціï : URL: https://regionet.org.ua/files/Dairy20directory20for20exporter1.pdf (дата звернення: 15.01.2019)._. Державна служба статистики України. URL: http://www.ukrstat.gov.ua (дата звернення: 15.01.2019). 4. Державна фіскальна служба України. URL: http://sfs.gov.ua. (дата звернення: 15.01.2019). 5. Джеджула В. В., Єпіфанова І. Ю., Гладка Д. О. Ринок молочної галузі: стан та тенденції розвитку URL: http://www.economyandsociety.in.ua/journal/18_ukr/53.pdf (дата звернення: 15.01.2019). 6. Електронний ресурc: URL: http://milkua.info/uk (дата звернення: 15.01.2019). 7. Євчук Л. А. Проблеми ринку молокопродуктів. Економіка АПК. 2002. № 12. 8. Мороз О. В., Карачина Н. П., Несен Л. М., Філатова Л. С. Обґрунтування функціональності ринку молочної продукції в Україні. Економіка, фінанси, право. 2014. № 12/1. С. 8. 9. Музичко Я. «Бутерброд без масла» Всеукраїнський журнал «Молоко і ферма», 2019, квітень, № 2 (51). URL: http://milkua.info/pdf/51-milkmag-all.pdf (дата звернення: 15.01.2019). 10. Савицька В. Актуальні проблеми розвитку ринку молока і молочних продуктів. Економіка АПК. 2002. № 11 С. 102-138. 11. Україна увійшла до ТOП-10 світових експортерів молочної продукції. URL: http://agroportal.ua/ua/news/zhivotnovodstvo/ukraina-voshla-v-top10mirovykh-eksporterov-molochnoi-produktsii/. (дата звернення: 15.01.2019).

\section{REFERENCES:}

1. Bozhydarnik T. V. Teoretyko-metodolohichni zasady implementatsii zarubizhnoho dosvidu rehuliuvannia rynku moloka u vitchyznianu praktyku. Ekonomichni nauky. Ser. Ekonomichna teoriia ta ekonomichna istoriia. 2013. Vyp. 10. S. 17-28. 2. Burka A., Hontar V., Kyshchuk O., Kostomakha V., Pankratov A., Polishchuk R., Shapoaval B., Yarmak A. Praktychnyi dovidnyk eksportera molochnoi produktsii

URL: 
https://regionet.org.ua/files/Dairy20directory20for20exporter1.pdf (data zvernennia: 15.01.2019). 3. Derzhavna sluzhba statystyky Ukrainy. URL: http://www.ukrstat.gov.ua (data zvernennia: 15.01.2019). 4. Derzhavna fiskaIna sluzhba Ukrainy. URL: http://sfs.gov.ua. (data zvernennia: 15.01.2019). 5. Dzhedzhula V. V., Yepifanova I. lu., Hladka D. O. Rynok molochnoi haluzi: stan ta tendentsii rozvytku URL: http://www.economyandsociety.in.ua/journal/18_ukr/53.pdf (data zvernennia: 15.01.2019). 6. Elektronnyi resurs: URL: http://milkua.info/uk (data zvernennia: 15.01.2019). 7. Yevchuk L. A. Problemy rynku molokoproduktiv. Ekonomika APK. 2002. № 12. 8. Moroz 0. V., Karachyna N. P., Nesen L. M., Filatova L. S. Obgruntuvannia funktsionalnosti rynku molochnoi produktsii $\mathrm{V}$ Ukraini. Ekonomika, finansy, pravo. 2014. № 12/1. S. 8. 9. Muzychko Ya. «Buterbrod bez masla» Vseukrainskyi zhurnal «Moloko i ferma», 2019, kviten, № 2 (51). URL: http://milkua.info/pdf/51-milkmag-all.pdf (data zvernennia: 15.01.2019). 10. Savytska V. Aktualni problemy rozvytku rynku moloka i molochnykh produktiv. Ekonomika APK. 2002. № 11 S. 102-138. 11. Ukraina uviishla do TOP-10 svitovykh eksporteriv molochnoi produktsii. URL: http://agroportal.ua/ua/news/zhivotnovodstvo/ukraina-voshla-v-top10mirovykh-eksporterov-molochnoi-produktsii/. (data zvernennia: 15.01.2019).

Bochko O. Y., Doctor of Economics, Professor (Lviv Polytechnic National University, Lviv), Maletska O. I., Candidate of Economics (Ph.D.), Associated Professor (Lviv National Agrarian University, Lviv), Savina N. B., Doctor of Economics, Professor (National University of Water and Environmental Engineering, Rivne)

\section{ANALYSIS OF THE EXPORT OF DAIRY PRODUCTS WITHIN THE CONTEXT OF EXTENSION OF THE EUROPEAN INTEGRATION CONDITIONS}

Milk is an obligatory component of the diet of every person. Nutritive value of milk and dairy products can be hardly overestimated.

The aim of the research is to outline scientific approaches concerning analysis and prospects of development of dairy products export within the context of extension of the European integration conditions. To make the investigation the authors have applied general scientific and specific methods of research, particularly inductive, deductive - for collection, systematization and processing of information, graphical for visual presentation of the results of statistical data, abstractlogical - for theoretical generalization and conclusions making.

Ukraine has recently entered the list of top 10 leaders of dairy products export. Among dairy products, the greatest share of export is taken by sweet butter and cheese. Those products were fast exported both in 2017 and in 2018 . In 2018, Ukraine imported dairy products to the amount of $\mathbf{2 0 . 9}$ million USD and exported milk and dairy products to the amount of $\mathbf{6 8 . 5}$ million USD. The products were mainly exported 
to Kazakhstan, Moldova, Morocco, Georgia, China, and Armenia. In the first quarter of 2019 , Ukraine received by $19 \%$ less income from dairy products transactions than in the same period of the last year, i.e. 53.9 million USD.

The dynamics of changes in export of dairy products is caused by different reasons, particularly, each country has its preferences; choice of an export direction requires investigation of trading regimes; Ukrainian exporters need to get EUR1 certificate; packaging and labeling should agree with the European standards; a wide range of products is needed for export.

To increase the volume of export, the authors of the work propose to create an informative platform, which should supply the full range of services to support foreign trade of Ukraine; to find wholesaling and retailing distributors in the exporting country; to increase the level of investments in products promotion at the international markets; to minimize efforts for search of a niche at the market and focus attention on its development; to create a mechanism of state regulation; to improve the existing regulatory base.

Keywords: export, dairy products, milk, raw materials, milk production, exporting countries.

Бочко Е. Ю., д.э.н., проф. (Национальный университет «Львовская политехника», г. Львов), Малецкая О. И., к.э.н, доц., (Львовский национальный аграрный университет, г. Львов), Савина Н. Б., д.е.н., профессор (Национальный университет водного хозяйства и природопользования, г. Ровно)

\section{АНАЛИЗ ЭКСПОРТА МОЛОЧНОЙ ПРОДУКЦИИ В КОНТЕКСТЕ РАСШИРЕНИЯ УСЛОВИЙ ЕВРОИНТЕГРАЦИИ}

Статья раскрывает результаты анализа экспорта молочной продукции в контексте расширения условий евроинтеграции. Установлено, что среди молокопродуктов больше экспортировали масло сливочное, сыры, а также молоко сгущенное. Представлена динамика экспорта молочных продуктов и стран экспортеров в 2017-2018 гг. Обзор и установлены основные страны-экспортеры молочной продукции, среди которых Казакстан, Молдова, Марокко, Грузия, Китай, Армения. Выявлены причины динамики изменения экспорта молочной продукции. Внесены предложения для увеличения объемов экспорта молочной продукции.

Ключевые слова: экспорт, молочная продукция, молоко, сырье, производство молока, страны-экспортеры. 